\title{
Supply chain integration in the South African conveyancing environment
}

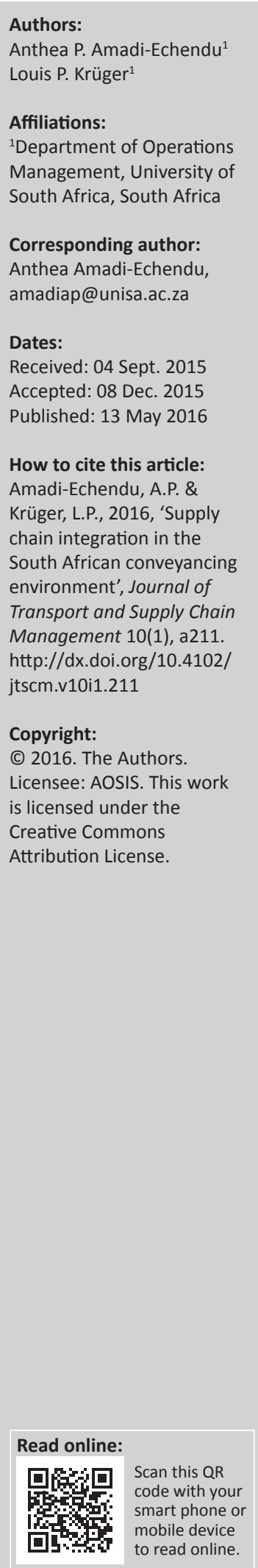

Background: Although conveyancing is a legal term, business management and specifically operations management principles also apply to the processes involved in conveyancing. From a business perspective, each organisation is usually concerned with its own profit margins and processes. In our global market, however, organisations now realise that they can no longer compete successfully on the basis of their internal operational efficiencies alone. They are therefore constantly aware of the need to improve not only their internal processes but also their alignment with other supply chain linkages in an effort to optimise the performance of the whole supply chain. Such alignment, in the conveyancing environment, includes government departments that are generally less willing to adopt business principles, which in turn makes optimisation of the whole supply chain more difficult.

Objectives: The article describes a supply chain perspective of the conveyancing processes in South Africa and reports some of the factors that influence and delay conveyancing transactions. It explores possibilities of collaborative relationships between different role players in the conveyancing supply chain. It aims to show that a supply chain approach, as opposed to a singular organisational approach, can help to reduce process bottlenecks and delays in order to improve overall process efficiency.

Method: The research, on which the findings are based, was exploratory in nature and followed a mixed-methods (quantitative or qualitative) approach and included both structured questionnaires and personal interviews.

Results: The results of the study revealed that many different types of delays occur at various entities across the whole supply chain involved in property transfers. These delays are presented in a table and diagram.

Conclusion: It is recommended that greater adoption of electronic technology across the whole supply chain would improve overall efficiency, eliminate bottlenecks and contribute towards efforts to optimise the conveyancing supply chain in South Africa. In addition, it is also recommended that the South African deeds registry implement an electronic system which would allow for the electronic lodging of property transfers.

\section{Introduction}

The idiom 'a chain is no stronger than its weakest link' is possibly what provided the impetus for the originator and business management guru, Eliyahu M. Goldratt, when he developed the theory of constraints as first documented in the book, The goal: A process of ongoing improvement (Goldratt \& Cox 1992:138). In it he wrote: '... we shouldn't be looking at each local area and trying to trim it. We should be trying to optimize the whole system ...' This is what supply chain integration should be about.

The business environment is made up of a system of individuals and organisations that produce goods and services to meet people's needs (Lofti et al. 2013). The task of management in this context is to examine the factors and methods that enable it (the business) to function as productively as possible as well as to maximise its profits whilst achieving its goals and objectives (Nieuwenhuizen \& Rossouw 2008:1). Operations management refers to the management of the activities that take place in the organisation to develop and produce products and services (Slack, Chambers \& Johnston 2010:4). It involves a transformation process of various inputs and is responsible for the output (products and/or services) of the organisation. Operations management does not, however, exist in isolation. It is inter-dependent on various other

Note: This article is partially based on the author's thesis of the master of commerce degree in the subject Business Management at the University of South Africa, South Africa, with supervisor: Prof. R. Pellissier, received November 2013, available here: http://uir.unisa. ac.za/bitstream/handle/10500/14148/dissertation_amadai-echendu_a.pdf?sequence $=1$ 
departments and functions in order to ensure the optimal functioning of the business as a whole (Tan, Pan \& Zuo 2014). Companies no longer compete as entities alone, but rather, with the involvement of their entire supply chain (Christopher 1999). Therefore, the outputs or deliverables flowing from the operations of the organisations within a particular supply chain actually compete with those of other (competitor) supply chains.

The 'common perception of conveyancing in South Africa is that conveyancing processes take too long and that conveyancing is inefficient and ineffective because the business processes necessary for the acquisition and transfer' of land or 'property assets comprise complex transactions between a variety of stakeholders.' This led to the research question: How can the 'efficiency and effectiveness of conveyancing be improved' within 'the South African context' (Amadi-Echendu 2013)? The article explores the possibilities of collaborative relationships between different role players in the conveyancing supply chain. It aims to show that a supply chain approach, as opposed to a singular organisational approach, can help to reduce process bottlenecks and delays in order to improve overall process efficiency. Information technology (IT) that is shared across the supply chain can assist with increasing collaboration across all supply chain partners and streamline the current property transfer process. Apart from data gathered through structured questionnaires, various semi-structured interviews were held with different role players involved in the transfer of property in order to determine the possible reasons for delays in property transfers. It is thus considered imperative that the whole supply chain in conveyancing be optimised and not merely the individual entities involved in the process.

\section{Defining a supply chain}

A supply chain can be described as a series of organisations, which include suppliers, distributors and the end customers who may be involved in different processes and activities to produce products and services for both upstream and downstream customers (Lofti et al. 2013) as well as information flow amongst supply chain members that create a network structure (Cheng, Chen \& Chen 2014). It includes all functions, whether directly or indirectly, that are involved in receiving and fulfilling a customer request (Inda et al. 2012). Lambert, Stock and Ellram (1998) define a supply chain as the alignment of organisations that bring products and services to the market. Supply chains exist, irrespective of whether they are managed. One organisation can also form part of numerous supply chains (Mentzer et al. 2001). A bank, for example, can form part of a transport and logistics supply chain as well as a property transfer supply chain. Various supply chain members can simultaneously interact in various channels, making the entire network a complex system (Cheng et al. 2014). A supply chain network is considered to be a complex inputs-outputs network system, in which input elements will be transformed into output elements via the purpose of the network structure (Long 2014). From a property transfer perspective, the input to the process is a willing buyer who completes an offer to purchase and the output is the transfer of the property to the buyer. Figure 1 attempts to illustrate the different role players involved in the conveyancing supply chain.

It is clear from Figure 1 that the many different role players and processes involved in property exchange contribute to making this a highly complex supply chain. The success of supply chain management depends largely on the organisation's efficiency in managing its processes (Loke et al. 2012). 'Supply chain management refers to the chain of all activities required for a business to transform inputs into outputs that customers are willing to exchange for value (Pearce \& Robinson 2005:159). Customarily, business and operations management focuses on the efficiency and effectiveness of business processes that occur within the operations' (Amadi-Echendu 2013) of an organisation. However, the supply chain extends beyond the internal structures of the organisation. It emphasises upstream and downstream linkages and the interconnection of related organisations through the processes that produce ultimate value to the consumer or end user (Christopher 1992). 'From an organisational and operations management' perspective, 'the goal is to achieve efficient and effective business processes' (Amadi-Echendu 2013). These can be achieved by enabling collaboration between the different supply chain members.

\section{Collaboration in supply chains}

Collaboration in supply chains can be defined as the cooperation between partners that are involved in a particular process, by means of information sharing, exchange of resources and the allocation of specific functions to enable mutual risk management and avoid disruptions (Badea et al. 2014). The objective of supply chain collaboration is ultimately to improve customer service ( $\mathrm{Li}$ 2012). When sudden changes occur in the market, the organisation can cooperate strategically with supply chain partners and respond to market changes in a cost-efficient manner (Ngai, Chau \& Chan 2010) that also reduces turnaround times and increases the customer experience. Supply chain collaboration means two or more autonomous organisations working jointly to plan and execute supply chain operations (Simatupang \& Sridharan 2002). Cross-functional collaboration simplifies an assessment of the state of the supply chain, the needs of the organisation and the determination of an approach that creates and sustains value (Oliva \& Watson 2011). Goals that might be difficult to achieve by individual organisations alone, might be achieved through value-based supply chain relationships (Koçoğlu et al. 2011). Collaboration should also be achieved amongst entities that are involved in conveyancing.

\section{Operations management and conveyancing}

'Conveyancing is the legal transfer of property from one owner to another. Ownership is mostly in the form of a real right, although limited real rights may also exist in the form 


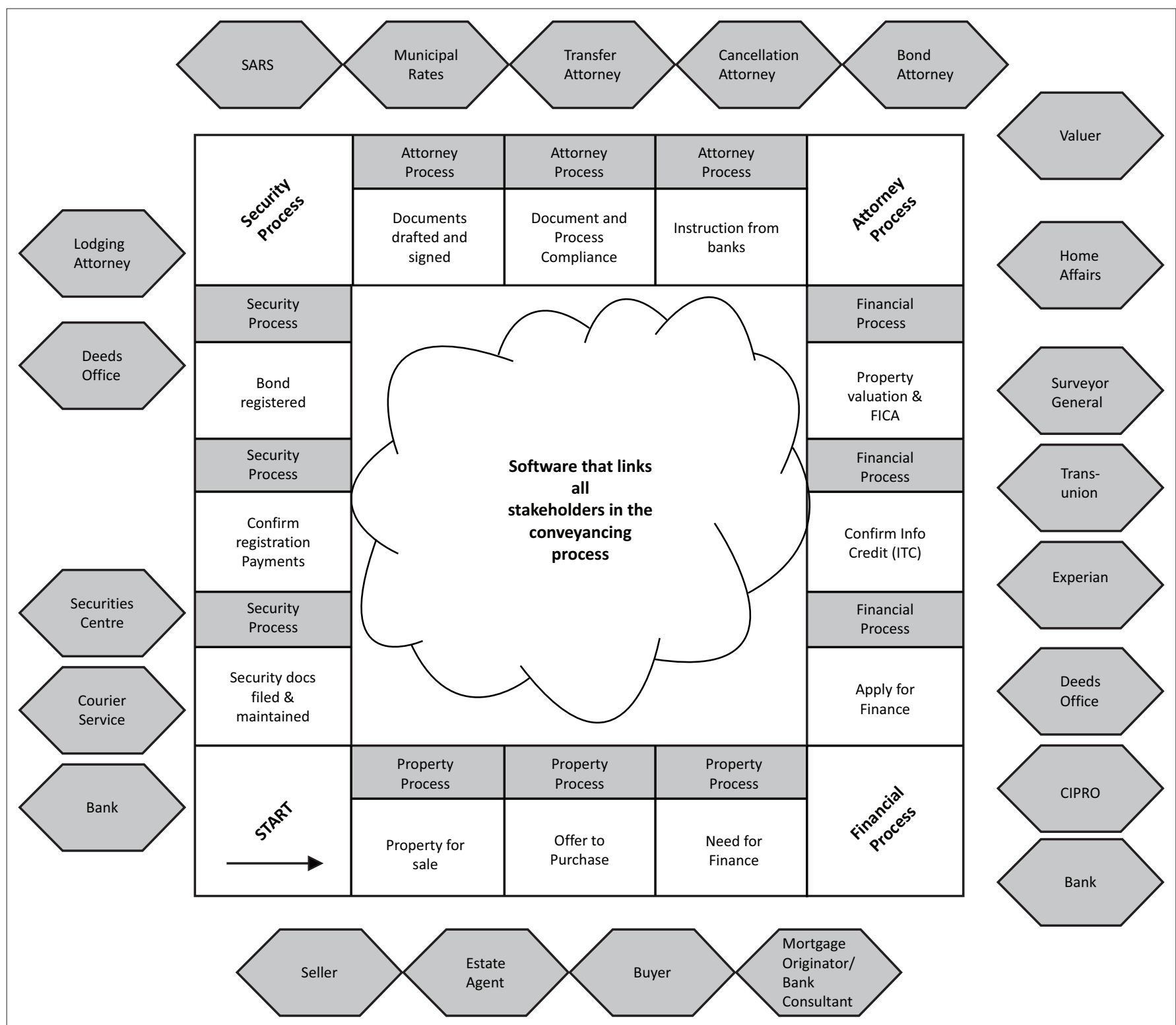

Source: Amadi-Echendu, A.P. \& Pellissier, R., 2013, 'Lessons for South Africa from the international e-conveyancing environment', in Global Business and Technology Association's 15th Annual International Conference, Helsinki, Finland, July 2-6, 2013

FIGURE 1: The conveyancing role players and processes.

of servitudes or other rights in property, for example, a creditor's right against the owner or registered leases (Van der Walt \& Pienaar 1999:45). Ownership is' generally 'defined in terms of legal rights - hence, conveyancing is perceived as a legal convention. The reality is that the actual transactions and activities that result in the transfer of ownership are derived from the specialised business processes of the various private firms and public agencies (role players) that are involved in conveyancing. Conveyancing involves business processes traditionally designed to transfer a landed property from one owner to another' (Amadi-Echendu 2013).

The 'business processes involved in conveyancing cut across the participating organisations and public agencies'. Hence, 'conveyancing business processes are not perceived in conventional organisation-level operations management', because their 'transactions and activities do not occur exclusively with an organisation or public agency. Rather, the various transactions and activities that constitute conveyancing business processes are institutionally' conducted 'by the different role players involved' (Wong et al. 2012), and 'this includes private organisations like banks and attorneys, as well as public agencies' such as municipalities, 'the Master of the Court and the Deeds Office registry'. The main point here is that, 'although conveyancing processes are wider in context than conventional organisationlevel business processes, the issues of process bottlenecks, efficiency and effectiveness also' exist 'and generally manifest in terms of cumbersome and tedious delays in the transfer of landed property from one owner to another' (Amadi-Echendu 2013).

'Parties and role players in a typical conveyancing process generally include estate agents, sellers, buyers, conveyancers, financial institutions, government agencies such as the Deeds Office registry', South African Revenue Services and 'local 
and municipal authorities (Ramwell, Brink \& West 2008:3). Where an estate of a deceased person is the seller', the Master of the Court 'may also be a role player. Depending on the roles and responsibilities of the various parties involved, a typical conveyancing interaction can involve many and' extremely complex transactions. For instance, Gordon, Nell and Bertoldi (2007) indicate that some transactions can take between 2 and 6 'months to complete because of the cumbersome and tedious interactions between the associated role players' (Amadi-Echendu 2013).

'In some cases, the transactions that are included in a single property exchange may involve several different attorney firms, each of whom represents' the respective role players, and all of whom will be 'required to lodge their respective documents at the Deeds Office registry. Where more than one property is involved, the transactions may be linked to even more role players'. The process tends to be exacerbated when 'the transactions involve manual interlinks and information transfer loops between the various role players. Even automated processes are not immune to risks that may arise, for example, from data inaccuracies and asynchronous time delays' (Amadi-Echendu 2013). The structure of the supply chain may influence the processes involved and how these processes are executed in practice.

\section{Structuring of the conveyancing supply chain}

In 'South Africa, deed registration is conducted by the Department of Land Affairs through its' 10 'Deeds Offices under the supervision of the Chief Registrar of Deeds. South African land registration is based on statute' (AmadiEchendu 2013) (Deeds Registry Act; see Republic of South Africa 1981) and the Alienation of Land Act (see Union of South Africa 1937) and is 'nominally based on characteristics of a positive and negative land registration system (Ramwell et al. 2008)' (Amadi-Echendu 2013). It is nominally negative, but contains some elements of a positive system, thus making the South African system completely unique. The 'security of title that South African titleholders enjoy is not the result of a state guarantee (as with a positive system), but a private-public partnership between the deeds' registry 'and the conveyancing profession' (Amadi-Echendu 2013). The different relationships between the various role players are conceptually illustrated in Figure 2.

In the conveyancing supply chain, 'each entity focuses on its core competencies and allows other' organisations 'to contribute to the final product that is delivered to the end customer' who is the buyer and seller of the property. Estate agents focus on identifying buyers for properties that are for sale in the market; mortgage originators focus on acquiring finance for the buyer for property purchases at the best possible interest rate; 'banks focus on financing properties and conveyancers focus on legal processes' of title transfer and registration as well as the drafting and signing of the relevant documents as provided for in statute. 'However, all the individual competencies and processes of all the role

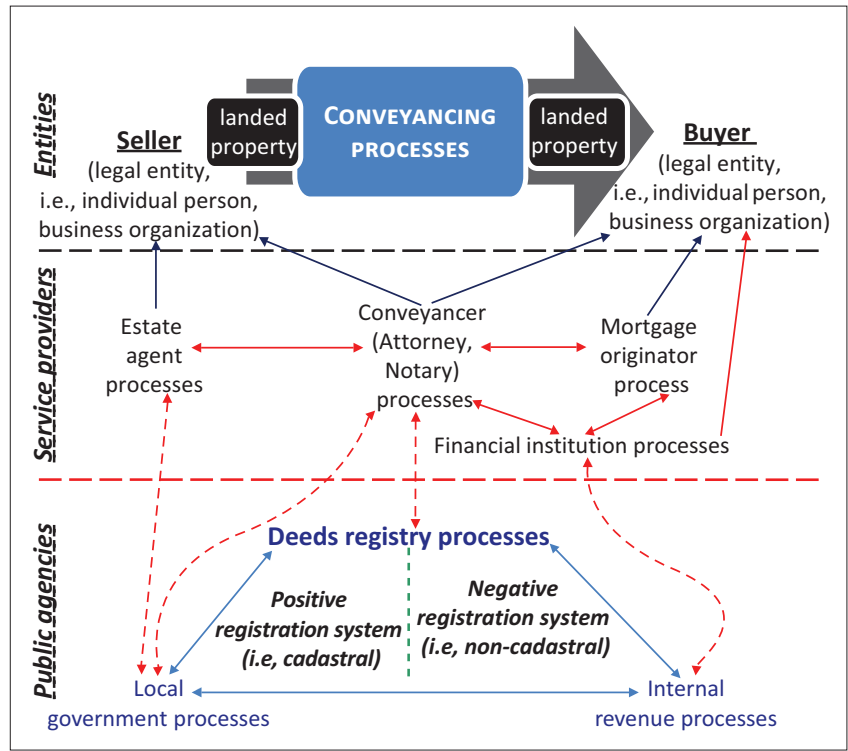

Source: Amadi-Echendu, A.P. \& Amadi-Echendu, J.E., 2013, 'Legal aspects of engineering asset management', in World Congress on Engineering Asset Management's 8th Annual International Conference, Hong Kong, China, October 30 - November 1, 2013

FIGURE 2: The conveyancing supply chain.

players form the conveyancing' supply chain. 'With each entity focusing on its own core competency, the structure allows for a sustainable competitive advantage for each individual' organisation only (Amadi-Echendu 2013).

Most of the stakeholders have a vested right in finalising the property transaction as commission is paid only when the title has transferred from seller to buyer. Banks also only start earning interest on the loan after the transfer has taken place. It is therefore understandable that banks in South Africa take responsibility for managing functions across the entire conveyancing supply chain in order to manage the supply chain processes. 'They provide feedback to estate agents and mortgage originators regarding the' financing 'of the loan and thereafter follow-up with conveyancers regarding the registration of the new title' (Amadi-Echendu 2013). It is generally agreed and accepted that a client becomes a client of the bank only once the bank has approved financing for the client, and the client has accepted the conditions of the loan. This is possible when the client formally signs a document (the quotation) that contains all the conditions of the loan, including the loan amount and interest approved for the particular transaction. Only on receipt of a signed quotation does a bank instruct an attorney to register a bond over the property in question. As a result, an estate agent or mortgage originator will keep the buyer abreast of the progress of the loan application until the attorney is 'instructed to register a bond in favour of the bank over' the property being bought (Amadi-Echendu 2013).

Certain non-core functions may be outsourced or subcontracted 'to specialists - for example, a bank may outsource the property valuation services to accredited specialists' (Amadi-Echendu 2013). A buyer is also allowed to acquire property insurance from another source that may not be the bank that has approved the loan for the purchase of 
the property. 'Different relationship types exist across the conveyancing' supply chain in order 'to manage the flow of information, products and finance. Relationships include business to business relationships (e.g. estate agency to bank, bank to attorney firm), business to consumer relationships (e.g. estate agent to seller, attorney to buyer) and consumer to business relationships (e.g. seller to estate agent, buyer to bank)'. As illustrated in Figure 2, the arrows indicate the relationships and the flow of information between the different role players. In addition to information flows, money also flows between the different entities.

\section{Financial cost implications of conveyancing}

Finance is also distributed to various role players. 'The property moves from seller to buyer, but the bulk of the money goes indirectly from the buyer to the seller, whilst a reasonable percentage of the value of the property is diffused throughout the supply chain as commission (to estate agents, mortgage originators), service charges (to attorneys' and banks), interest on loan (to banks and other financial institutions) 'and taxes (to SARS and municipalities). The seller pays a commission, which is included in the purchase price to the estate agent' for selling his or her house (AmadiEchendu 2013). This amount is payable after registration of the property has occurred at the Deeds Office registry, and the 'estate agent therefore retains a vested interest in seeing the property through to registration. Banks normally have signed contracts with mortgage originators whereby an agreed percentage of the loan amount registered is paid to the originator by the bank after registration' (AmadiEchendu 2013). Mortgage originators therefore also have a vested interest in the registration of the property in the name of the new owner.

Attorneys' charges are accrued, which are paid by the buyer (for the transferring attorney) or seller (for the cancellation and bond attorneys) before registration takes place. Attorneys take responsibility for various payments that must be made, including payment of taxes to municipalities and SARS, settlement of outstanding rates amounts or body corporate levies, deposits payable to banks, commissions to the relevant parties or settlement of accounts as per the conditions of the loan approved by the bank. Attorneys therefore acquire additional insurance to assist them in the event of any mistakes made in this regard. 'Banks charge interest on the loan advanced to buyers', and it 'is therefore in their interest to see to it that the property' is registered as soon as possible in order to start earning revenue (Amadi-Echendu 2013). Banks manage their panel attorneys and mortgage originators, who have signed contracts with them, by means of service-level agreements that manage registration turnaround times and the delivery of security documentation to banks within a specified timeframe after the transfer of title has occurred. At the same time, it is important for entities to deliver value to their customers (the buyers and sellers), whilst adequately managing their cost structures.
'Costs are incurred by individual operations of each organisation and additional costs are incurred by doing business across the' supply 'chain with other role players. These may include' the costs of setting up of contracts between different entities, 'monitoring performance, providing additional information to' more role players across the supply chain, referral bonuses and communication with and updates to other role players (Amadi-Echendu 2013). Banks retain the title deed document of properties that still have a bond registered in favour of the bank. These title deeds are stored in facilities that are fireproof of which the cost for the building, staff and related items are all carried by the bank. Lost title deeds are also replaced by banks, which significantly add to the cost, not to mention the time delay that occurs as a result of having to request copies from the Deeds Office registry. Without a copy of the existing title deed, new property transfers cannot be lodged with the Deeds Office registry. If these documents were to be stored electronically, the associated cost and turnaround times would be significantly reduced.

The 'effect of conveyancing processes may even be more significant if' it involves movements of labour, documents and business operations from one location or country to another location or 'where the landed property legislation' or procedures may be different (Amadi-Echendu 2013). South Africa has 10 Deeds Offices where transfer of ownership is recorded. Different Deeds Offices have different rules of engagement. Paper documents must be physically lodged with the Deeds Office in whose jurisdiction the property being transferred resides. These documents are then manually examined. A correspondent attorney is used if the transferring attorney attending to the transfer of the property is located in a different province, as the paper documents need to be delivered in person to the relevant Deeds Office registry. This indeed adds to the complexity and time delays associated with these types of transactions. These complexities may be better managed by introducing IT to electronically lodge the transfer with the deeds registry and to keep track of performances and progress of transactions across the supply chain.

\section{The role of information technology in conveyancing}

A supply chain is as strong as its weakest link (Li 2012). The one entity that delays the completion of a certain function delays the entire transfer transaction. Information systems comprise hardware, software, data, telecommunications, people and procedures (Hartono et al. 2010; Stair \& Reynolds 2012). However, providing the software and hardware alone is not sufficient as the supply chain members should also be willing to participate in information-sharing activities (Lofti et al. 2013). Using enterprise technology will enable a single entry point into an organisation's database, and the database can be shared by various departments in an organisation, as well as supply chain partners (Li 2012). This practice saves time, reduces data entry errors and contributes 
to reduced production costs, which results in better operational performance ( $\mathrm{Li}$ 2012). When dealing with property transactions in South Africa, each entity obtains its own information and manually enters this information into its technological systems. Introducing enterprise technology that is shared across all entities involved in the conveyancing supply chain would enable the information per transaction to be captured once at source (such as an estate agent or a mortgage originator), and the same information could be available across the supply chain for other authorised entities to access.

Information technology (IT) also enhances supply chain efficiency by providing real-time information (Devaraj, Krajewski \& Wei 2007). This means that each entity would at any point in time be able to track the progress of any transaction and could thus positively influence bottlenecks identified in the process. Inter-organisational IT necessitates huge investments that may not be met by the organisation's financial resources (Ye \& Wang 2013). The benefits of integrated IT include reduced communication and transaction cost (Muller \& Seuring 2007), improved efficiency in coordination (Sanders 2005), improved customer service and reduction in operational cost (Premkumar, Ramamurthy \& Crum 1997; Ye \& Wang 2013) and easy retrieval of paststored information to support current business, thus leading to improved customer responsiveness (Ye \& Wang 2013). Coordination amongst trading partners requires shared knowledge to enable the effective management of activities (Yu et al. 2013). To successfully implement supply chain management, organisations must overcome their own functional silos and adopt a process approach (Lambert et al. 1998).

Although operational performance is also improved by optimally using supply chain resources and capabilities, they must be embedded in the supply chain to enable synergy (Ye \& Wang 2013). In the South African conveyancing environment, each entity that is involved in the conveyancing supply chain, manages its own technological systems and processes. These processes do not necessarily integrate across the conveyancing supply chain. The benefits of IT are achieved through IT alignment with supply chain partners (Dong, Xu \& Zhu 2009) as this achieves synchronisation and coordination of complex supply chain activities amongst them (Thun 2010). In the South African context, integration of systems and processes across the conveyancing supply chain would need to be achieved and this in turn could help to improve the efficiency and effectiveness of the current conveyancing supply chain processes. The research methodology that was used in this research will be discussed next.

\section{Research methodology}

'There are two main paradigmatic approaches in research, qualitative and quantitative (Blumberg, Cooper \& Schindler 2008:191). A quantitative approach places greater value on information that can be numerically manipulated in a meaningful way, and this is regarded as the scientific approach to research (Page \& Meyer 2006). A qualitative approach can be conceptualised as a focus on words and feelings about an event or experience (Page \& Meyer 2006). This study' involved 'both quantitative and qualitative research approaches. Mixed-methods research is a research design that employs philosophical assumptions' in addition to 'methods of inquiry. As a methodology, it involves philosophical assumptions that guide the direction of the collection and analysis and the mixture of qualitative and quantitative approaches in many phases of the research process' (Creswell \& Plano Clark 2011). 'As a method, it focuses on collecting, analysing and mixing both quantitative and qualitative data in a single study or series of studies. Its central premise is that the use of qualitative and quantitative approaches, in combination, provides a better understanding of research problems than either approach alone' (Creswell \& Plano Clark 2011:5). This research followed a mixed-methods approach. Parallel timing occurred in this study whereby quantitative and qualitative data were collected, analysed and interpreted approximately at the same time (AmadiEchendu 2013).

The targeted population for this study (for both quantitative and qualitative components) were role players who have been involved in property transfers over the last 5 years. Although there are many more role players, 'it was assumed that the transactions occurring between the selected role players are significantly' representative of all others. 'Because of their size, there are likely to be many more transactions occurring amongst the bigger role players. The Internet, property-related magazines and related books were used to locate the names of relevant people' for the quantitative research (Amadi-Echendu 2013). The requirement was that buyers and sellers needed to have bought or sold a property within the last 5 years to qualify to be a respondent and that all other respondents had to be actively involved in property transfers. The seniority of the participants (for the qualitative study) and respondents (for the quantitative study) were not as important for the purposes of the study, but rather their experience with regard to property transfers and the number of transactions that occurred in their firms.

'A purposive sample consists of respondents who, in the' opinion of the researcher, would 'best supply the necessary information (Page \& Meyer 2006:99). In' the qualitative study, a purposive sampling method was used and semi-structured interviews were conducted with national representatives of two of 'the four major banks (the other two' banks did not consent to the interviews), the Estate Agency Affairs Board $(\mathrm{EAAB})$, The Services Seta, a national manager from the larger and oldest mortgage originator in SA and a manager from a municipality. Although international interviews were conducted as part of the bigger study, the data collected from those interviews fall outside the scope of the article. Table 1 lists the participants who were interviewed in South Africa (Amadi-Echendu 2013). 
TABLE 1: Participants interviewed.

\begin{tabular}{llc}
\hline Firm represented & Position of participant & $\begin{array}{c}\text { Number of people } \\
\text { interviewed }\end{array}$ \\
\hline Suzie at Bank A & National attorney liaison & 1 \\
Lisa at Bank B & National sales liaison & 1 \\
Dan at Estate Agency Affairs Board & National training manager & 1 \\
Bongi at Services Seta & Portfolio manager & 1 \\
Anne at Mortgage Originator & Franchise manager & 1 \\
Stan at Municipality & Legal manager & 1 \\
\hline
\end{tabular}

A copy of the quantitative questionnaire and the qualitative interview questions were sent to each participant 'before the interview to allow each person to adequately prepare for the interview and to remove all elements of surprise. Banks are extremely competitive and it was important for each bank to understand that the questions were not intrusive' or threatening to their businesses (Amadi-Echendu 2013). The main aim of the interviews was to determine how the efficiency and effectiveness of the current processes could be improved. The identity of the interviewees was protected by removing all information that could identify them and keeping all respondents anonymous. The content of the interviews was digitally recorded. The qualitative interviews were transcribed and analysed by means of content analysis. Various themes were identified, and the information was clustered according to these themes. The main themes were complexity, cumbersomeness, tediousness, effectiveness and efficiency.

Validity and dependability are terms associated with qualitative research. 'According to Saunders et al. (2003:101), in terms of validity, the concern is whether the findings are really about what they appear to be about. One of the objectives of this study was to analyse and interpret data from qualitative data obtained through interviews' (AmadiEchendu 2013). A purposive sampling allowed the researcher to select participants from whom up-to-date and relevant knowledge about property transactions could be obtained. To increase the level of trustworthiness of the study, a recording device was used as a primary tool during the local interviews, which also provides an unbiased record of each conversation. The researcher was personally responsible for data collection. Different types of questions were asked to ensure that consistent answers were given. The researcher began to analyse information after the first interview to facilitate subsequent data collection (Strauss \& Corbin 1998). This constant monitoring and confirmation of the research process as a verification strategy helped to ensure rigour. The interviews were transcribed verbatim and the researcher maintained a neutral role in the research. A consistent coding method was used to increase the trustworthiness in the study.

For the quantitative study, six separately structured questionnaires for each of the respondent groups 'were used to gather information' pertaining to 'the process of conveyancing in South Africa. The respondent groups included buyers, sellers, estate agents, mortgage originators, banks and' conveyancers. 'Questions were developed across the entire' property transfer 'process to measure the turnaround time of certain steps and also to confirm certain steps and information in the process. The options were divided into five Likert scales' from 'which the respondents had to choose. All the questions were mandatory, except for the questions' pertaining 'to financing, as some of the immovable property could have been purchased for cash. The questionnaires were' captured onto the Lime Survey and the link was emailed to the respondents (Amadi-Echendu 2013). The respondents were identified by means of a snowballing technique. The quantitative data collected were captured on the Lime Survey and analysed by means of statistical analysis. Table 2 provides a summary of the major role players used in the study.

'Total reliability would mean that the same results will be obtained if the study is repeated. Cooper and Schindler (2006:716) define reliability as a characteristic of measurement concerned with accuracy, precision and consistency. Various steps were taken to ensure the validity of the results. These included consultation with an expert in questionnaire design. The process issues were also tested in a quantitative questionnaire that was' piloted with some respondents before rolling it out on a larger scale. The 'reliability and validity of measures taken during the research reflect the level of confidence one can have in the results yielded by the research design. They determine whether results can be generalised to a population (Page \& Meyer 2006:84). Reliability analysis was not conducted' because 'some of the sample' size was 'small for some entities, for example banks had eight respondents. Not all the 17 registered banks with the Reserve Bank are involved with mortgage loans and two of the banks did not consent to participate in the study. The questionnaire was also not structured to measure constructs or dimensions. The items or questions are independent and measure different aspects.' The aim of this study was not to generalise to the whole population, but to gain insights into conveyancing processes. 'A copy of all the completed questionnaires was kept on file together with all the email' correspondences (Amadi-Echendu 2013).

Triangulation is a validity procedure where researchers search for convergence amongst different sources of information in order to form themes in research. Denzin (1978) identified four types of triangulation, namely across data sources, theories and methods and amongst different investigators. Data sources do not mean using different methods, for example the use of multiple interviews would provide multiple data sources whilst using a single method (Johnson 1997). Another important part of data triangulation

TABLE 2: Respondents of questionnaires.

\begin{tabular}{lcc}
\hline Respondent & $\boldsymbol{N}$ & $\mathbf{\%}$ \\
\hline Conveyancer & 146 & 51.2 \\
Estate & 19 & 6.7 \\
Mortgage originator & 6 & 2.1 \\
Seller & 36 & 12.6 \\
Banks & 8 & 2.8 \\
Buyers & 70 & 24.6 \\
\hline Total & $\mathbf{2 8 5}$ & $\mathbf{1 0 0 . 0}$ \\
\hline
\end{tabular}


involves collecting data at different times, at different places and with different people. The study collected qualitative data from different data sources, namely banks, estate agents, mortgage originators, conveyancers, buyers, sellers, the EAAB and the Services Seta. This constitutes triangulation across data sources. In addition, data via quantitative questionnaires were obtained from various data sources, namely buyers, sellers, estate agents, mortgage originators, conveyancers and banks; and a literature study was carried out which achieves triangulation by methods. Table 2 illustrates the different groups that took part in the quantitative questionnaires.

As indicated in Table 2, 'the largest group of respondents were conveyancers', which accounts 'for more than half of the total number of respondents' who participated in the research (Amadi-Echendu 2013).

\section{Results}

The primary objective of the study was to investigate the South African conveyancing system 'with a focus on how to improve the efficiency and effectiveness of the conveyancing processes' from a supply chain perspective (Amadi-Echendu 2013). Only the delays and bottlenecks identified in the research are highlighted in the article. Various delays and bottlenecks are associated with the various 'role players involved in the end-to-end conveyancing process' (AmadiEchendu 2013). These bottlenecks identified were mapped from the quantitative and qualitative data collected in the study. All bottlenecks were identified for the different role players. In the quantitative questionnaires, an open-ended question asked respondents to list the top five delays they experience in property transfer transactions. Table 3 reflects reasons of delays in alphabetical order regarding property transfers that were identified in the quantitative questionnaires.

The delay reasons that were 'put forward by the different role players occur throughout the end-to-end service chain. The delays are also caused by different role players, and no one

TABLE 3: Delay reasons offered by respondent groups.

\begin{tabular}{ll}
\hline Delay reasons put forward by respondent groups & Responsible party \\
\hline 90-day penalty & Bank \\
\hline Agents, sellers and purchaser tax number for SARS & Municipality/Bank \\
$\begin{array}{l}\text { Amended instructions } \\
\text { As at 30 April: Deeds Office taking up to 15 working } \\
\text { days for registration }\end{array}$ & Bank \\
Attachments & Deeds Office \\
$\begin{array}{l}\text { Awaiting proceed from bank to register } \\
\text { Bank cancellation amounts }\end{array}$ & Bank \\
$\begin{array}{l}\text { Bank delays - amendments, deeds, etc. } \\
\text { Bond cancellation attorney who do not sign their } \\
\text { own consents }\end{array}$ & Bank \\
$\begin{array}{l}\text { Bond instructions sent to attorneys not in same } \\
\text { town as client }\end{array}$ & Bank \\
$\begin{array}{l}\text { Bond not approved for correct amounts } \\
\text { Bond instructions with life insurance condition }\end{array}$ & Attorney \\
Bond registration formalities & Bank \\
\hline
\end{tabular}

TABLE 3 (Continues...): Delay reasons offered by respondent groups. Delay reasons put forward by respondent groups Responsible party Bonds: incorrect instructions that have to be amended Bank Building loans and developments Building loans: valuation reports Municipality/Bank Buyer and seller to sign Cancellation attorney

Cancellation figure dependent on bank Valuers

Cancellation instructions sent to attorneys not in same town

Cancellation of bonds for other banks

Cancellation proceed to lodge

Buyer/Seller Attorney

Bank

Attorney

Cancellation where Financial Intelligence Centre Act not in place

Cancellations/release figures

Certified copies and endorsed Power of Attorney (Transfer) from Master

City council clearance certificate

City of Johannesburg - obtain clearance certificate Clearance (Council) and HOC clearance

Client delays (finances, etc.)

Client not appreciating urgency of cooperation

Client not paying costs timeously

Clients are not FICA compliant

Banks/Attorneys

Banks

Buyer/Seller

Bank

Master

Municipality

Municipality

Municipality/Bank

Buyer/Seller

Buyer/Seller

Buyer/Seller

Buyer/Seller

Clients furnishing the attorneys with the correct FICA documentation

Clients not properly informed of Rights \&

Obligations, e.g. Costs

Clients signing abroad

Buyer/Seller

Clients who do not perform on time

Companies office

Complying with suspensive conditions and contractual disputes

Copies from Vryburg Deeds Office if lost

Copy deed from transfer attorneys

Estate Agent

Dealing with government and some government institutions

Deceased/insolvent estate delays at Master

Deed of sale/application of bond

Buyer/Seller

Buyer/Seller

CIPRO

Attorneys

Deeds Office

Attorney

Government institutions

Deeds Office delays - they take too long to register

Deeds Office occasionally

Deeds Office rejections

Delays in receiving title deeds from bondholder

Delays in receiving Transfer Duty receipt from SARS

Deposit and costs not paid

Dispute between parties

Distances between clients, our offices and the

deed's offices

Divorce

Master

Bank

Deeds Office

Deeds Office

Deeds Office

Bank

SARS

Buyer/Seller

Buyer/Seller

Attorney

Documents lost

Buyer/Seller

Draft deed and Guarantee requirements from

transferring attorneys (on bonds)

Electrical compliance certificates

All

Attorney

Endorsed power of attorney - Subdivision

Endorsement Master

Erroneous instruction from the bank

Estate late/insolvency/sheriff transfers

Seller

Municipality

Master

Bank

Estate transfer/insolvent transfer/divorce transfer

Existing property to be sold

External life cover noting letter

FICA compliance

Finance

Fulfilment of restrictive conditions

Getting POA endorsed by the Master

Guarantees from bond attorneys

HOAs or Body Corporates

Master/Sheriff

Master/Sheriff

Buyer/Seller

Buyer/Seller

Buyer/Seller

Buyer/Seller

Attorney

Master

Attorney

Body corporates,

Insurance companie

Table 3 continues on the next page $\rightarrow$ 
TABLE 3 (Continues...): Delay reasons offered by respondent groups.

\begin{tabular}{|c|c|}
\hline Delay reasons put forward by respondent groups & Responsible party \\
\hline Holiday & All \\
\hline Huge outstanding amount with council & Seller \\
\hline If finances are linked to another sale of property & Buyer/Seller \\
\hline Income tax issues & SARS \\
\hline Incomplete documents & All \\
\hline Incorrect/unclear Instructions & Bank \\
\hline $\begin{array}{l}\text { Incorrect bond instructions in respect of home } \\
\text { owners insurance }\end{array}$ & Bank \\
\hline $\begin{array}{l}\text { Incorrect details on bond instructions/sale } \\
\text { agreements }\end{array}$ & Bank \\
\hline Information from clients & Buyer/Seller \\
\hline Instruction from transferring attorney & Attorney \\
\hline Internet (all programmes linked) & Technology \\
\hline $\begin{array}{l}\text { Lack of knowledge, unavailability and } \\
\text { non-co-operative clients }\end{array}$ & Buyer/Seller \\
\hline Levy and home owners ass clearance certificate & Body Corporate \\
\hline Life assurance policies + noting of interests & Life Insurance Companies \\
\hline Life cover and home owners cover & Life Insurance Companies \\
\hline $\begin{array}{l}\text { Link transactions taking too long/Simultaneous } \\
\text { attorneys taking too long }\end{array}$ & Attorneys \\
\hline Linked to sheriff/Property In Possession transfers & Sherriff/Bank \\
\hline Linked transfers & Attorneys \\
\hline Linking with other attorneys & Attorneys \\
\hline $\begin{array}{l}\text { Linking with slow unqualified (non-conveyancers) } \\
\text { transferring attorneys }\end{array}$ & Attorneys \\
\hline $\begin{array}{l}\text { Lost deeds and Deeds Office delays, slow reaction } \\
\text { times of parties }\end{array}$ & All \\
\hline Lost title deed and mortgage bond documents & Bank \\
\hline Marital status that change after signing & Buyer/Seller \\
\hline New development & Municipality \\
\hline $\begin{array}{l}\text { Non-reading of metres by Municipality resulting in } \\
\text { 'interim' figures - BIG DELAY }\end{array}$ & Municipality \\
\hline $\begin{array}{l}\text { Not receiving proper instructions and then later } \\
\text { you have to obtain and supply further documents }\end{array}$ & Bank \\
\hline Obtain building documents & Bank/Buyer/Seller \\
\hline $\begin{array}{l}\text { Obtaining draft deed and guarantee requirements } \\
\text { from transferring attorneys }\end{array}$ & Attorney \\
\hline Obtaining rates clearance figures from Marigaling & Municipality \\
\hline Obtaining supporting docs from client & Buyer/Seller \\
\hline $\begin{array}{l}\text { Old mortgage bonds where the account number } \\
\text { cannot be traced }\end{array}$ & Bank \\
\hline Original title deed from bank for further loan & Bank \\
\hline Outstanding taxes or not registered with SARS & SARS \\
\hline PIP, foreclosure and eviction & Bank/Sheriff \\
\hline Poor instructions and preparation by estate agents & Estate Agents \\
\hline Postal delays & Post Office \\
\hline Rejections at Deeds Office & Deeds Office \\
\hline Securities & Bank \\
\hline Simultaneous transfers of other properties & Attorney \\
\hline Special conditions on deed of sale & Attorney/Bank \\
\hline Striking of relevant organisations & Attorney \\
\hline Sub-divisional transfers & Municipality \\
\hline Subject to sale funds to come from proceeds & Attorney/Buyer/Seller \\
\hline $\begin{array}{l}\text { The City of Johannesburg - when obtaining a rates } \\
\text { clearance certificate }\end{array}$ & Municipality \\
\hline Transferring attorney & Attorney \\
\hline Trustees in insolvent estates & Trustees \\
\hline Tshwane-change of owner's details & Municipality \\
\hline Uplifting interdicts against the property & Bank/Court \\
\hline Valuations of the property & Valuer \\
\hline Waiting bond approval and subsequent instruction & Bank \\
\hline Waiting for other firms & Attorney \\
\hline Waiting on parties to complete financial matters & Buyer/Seller \\
\hline Waiting on parties to sign documents & Buyer/Seller \\
\hline Waiting out penalty periods & Buyer/Seller \\
\hline When seller's liabilities exceeds purchase price & Buyer/Seller \\
\hline
\end{tabular}

particular group can take responsibility for the delays. This makes it all the more important for the end-to-end conveyancing service chain to be managed in terms of a supply chain' as discussed in the literature (Amadi-Echendu 2013). Many inefficiencies and delays were highlighted during the qualitative interviews conducted as well.

'A lack of knowledge and experience, however, has resulted in many incomplete and/or incorrect' offers to purchase (OTP) 'agreements, which may lead to unnecessary delays and/or disputes between the relevant parties' (AmadiEchendu 2013). As stated by Suzie:

'I think there is such a lack of knowledge in the market now ... I also believe there are a lot of fly by nights, a lot of rookies that have no clue what they are doing. They just sign an offer, we talk about OTPs, left right and centre, and then make it our problem to obtain the applications through. And sometimes it's a dead horse before you start.' (Participant 4, Female, National liaison)

Anne confirmed the importance of adequate knowledge by saying that:

'the level of expertise in the industry to be able to interpret information correctly and assist the buyers without undue errors that result in delays is also noted by different role players. One of the things that we try and do is to educate estate agents on understanding the importance of concluding the sale agreement correctly so that it will reflect the party's intentions, so it is understandable and most important of all, legally enforceable.' (Participant 5, Female, National liaison)

An increase in knowledge could translate into fewer errors across the property supply chain, which could decrease the number of delays.

'Numerous references were made to electronic interventions by different respondents during the interview process. These electronic interventions were positioned to have improved and expedited the property processes of the' individual respondent groups (Amadi-Echendu 2013). It was confirmed during the data collection process that each entity in the conveyancing supply chain collects its own data and supporting documents, which leads to a lot of duplication. In addition, each entity enters the necessary information into its own electronic technology to manage and track the progress of its transactions. Much reengineering of processes has taken place, but these improvements seem to have happened within different entities and not across the different role players in the conveyancing supply chain. As a result, reengineering has not removed the duplication, which riddles the current process. As stated by Dong et al. (2009) and Ye and Wang (2013), IT capabilities embedded in the supply chain resources and IT alignment across supply chain partners by means of IT integration will improve operational performance.

'Estate agents manage efficiencies by promoting sole mandates', whilst 'banks try to manage efficiencies and effectiveness across the property' supply 'chain by using service-level agreements, which are strictly enforced. 
Mortgage originators try to improve efficiencies in the property' supply 'chain by 'taking the paperwork out of the process for the potential buyer" (Participant 5, Female, National liaison) (Amadi-Echendu 2013).

'They also try to proactively assess buyers by introducing a prequalifying process as part of their function. The interview with the mortgage originator also made reference to the implementation of an electronic system that would enable banks to view the bank statements of other banks for the transactions they need to assess.' (Amadi-Echendu 2013) This also points to IT alignment and interfaces. Currently, buyers must supply financial institutions with manual copies of other banks' statements. Particular attention is drawn to the perception of how a shared network would assist to expedite applications for finance and other functions across the end-to-end process. In addition, it could highlight fraudulent transactions as well as multi-bank applications for the same property.

'Service-level agreements and mandates are used to manage processes across different role players in the end-to-end conveyancing process. Reward and recognition strategies have also been linked to performance in terms of servicelevel agreements and mandates. This forces role players to comply with' obligations contained in 'these agreements and results in competition between role players, especially if they operate on the same playing field'. It is interesting to note that benchmarking was only mentioned by the EAAB in 'their interview. This gives the impression that all the other role players are more internally focused and do not necessarily take learning from other countries or entities that appear to be more successful' (Amadi-Echendu 2013).

Obtaining tax certificates and municipal rates clearance certificates has been highlighted by many respondents as a major bottleneck in the conveyancing process. Suzie indicated 'I think the municipality leg is the worst' (Participant 4, Female, National liaison). Although according to Lisa 'many people often say that attorneys delay the process on purpose ...' (Participant 3, Female, National liaison), Anne stated the opposite: 'I don't find that attorneys on purpose delay a registration ...' (Participant 5, Female, National liaison). The transferring attorney has the responsibility of ensuring that all the processes and clauses have been fulfilled and complied with as was confirmed by Suzie: 'Bond cannot proceed until all those internal processes within all the three attorneys are sorted out' (Participant 4, Female, National liaison). This was confirmed by Lisa. As a result, attorneys are often blamed for delaying the process: 'most of the delays are on the transfer side in general' (Participant 3, Female, National liaison).

Research themes that were investigated in the bigger study were complexity, effectiveness, efficiency, cumbersomeness and tediousness. Various sub-themes were identified from the qualitative interviews, which included compliance, electronic interventions, fraud, process inefficiencies, turnaround time, supply chain dependencies, process risks and delays. Linkages amongst categories and sub-categories were established by means of axial coding. For the purposes of the article, selective coding was used where delays were identified as a core category. For the purposes of the article, only the delay reasons were extrapolated from both the qualitative and quantitative data. A list of these delay reasons that were compiled in Table 2 and as highlighted in the qualitative interviews was grouped as they occur amongst the different entities. A peer debriefer reviewed the grouping thus adding to the credibility of the study.

Triangulation of the different data sources and different methods used provided a means of confirming the delay reasons as no relationships were tested during the study. Both the quantitative and qualitative studies provided evidence to support the various delays identified. Therefore, it can be seen that the combination of quantitative and qualitative studies can corroborate evidence and as such enhance the external validity of the overall research.

This grouping is illustrated in Figure 3, which highlights common delays that were identified for the different entities involved in the end-to-end conveyancing process. These delays vary from outstanding documentation, to inadequate information forwarded by other role players, to third-party processes not completed timeously, postage delays, other legal processes that must be completed, for example, divorce proceedings, winding up of deceased estates and subdivisions. Many of these delays could be better managed if the transaction was more transparent and progress could be monitored by other supply chain members. As illustrated in the literature, this can be achieved by implementing information technologies.

\section{Conclusion}

Inter-organisational linkages facilitate information and data exchanges and reduce conflicts in supply chains (Cheng 2011). Processes are used to execute an organisation's operations and other functions, which collectively contribute to the customer's experience. The conveyancing processes cut across private and public entities, but in South Africa, they currently seem to be managed as if in individual silos. To successfully implement supply chain management, organisations must overcome their own functional silos and adopt a process approach. Much can be carried out to streamline the endto-end conveyancing process across the different entities involved. An electronic interface that cuts across the different entities (both private and public) could assist in creating a streamlined and smooth flow of information, money and resources. It would also accentuate the re-engineered efforts already employed by individual entities. This would allow for better cooperation between the supply chain stakeholders, which is bound to improve service quality and turnaround times. In a competitive global environment, this would certainly go a long way in improving the effectiveness and efficiency of conveyancing processes in South Africa.

It is recommended that electronic technology be introduced across the conveyancing supply chain in order to address 


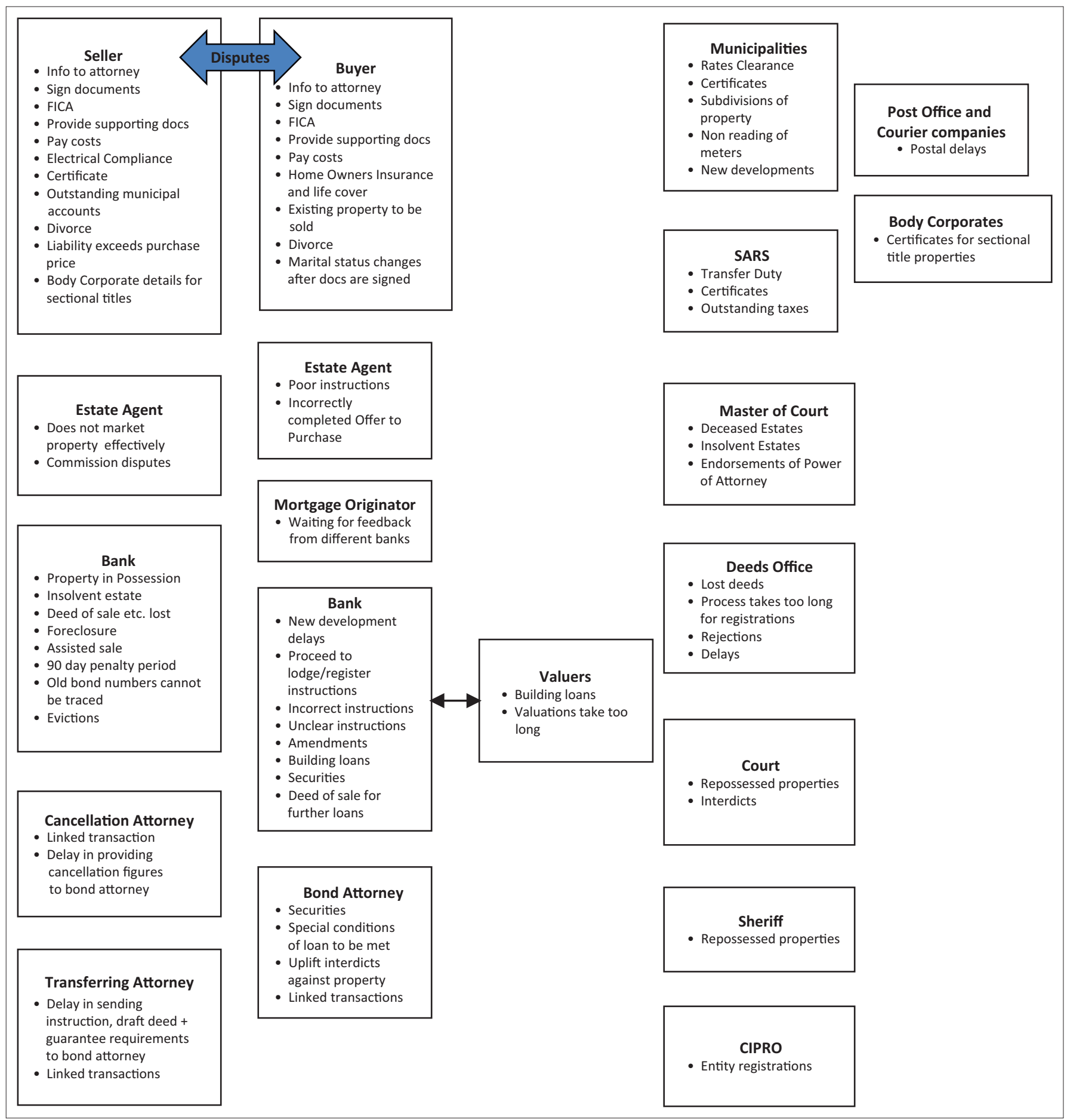

Source: Amadi-Echendu, A., 2013, 'An analysis of conveyancing business processes in South Africa', M.Com dissertation, University of Pretoria, Pretoria FIGURE 3: Delay reasons identified by the various stakeholders.

some of the inefficiencies and delays highlighted by the research. This would also help to expose current delays and eliminate bottlenecks in the system because of the increased visibility and transparency that would then exist across the whole property supply chain. It could also reduce transcription errors that regularly occur because information is separately captured by several organisations over and over again.

In addition, it is also recommended that the South African Deeds Registry implement an electronic system, which would allow for the electronic lodging of a property transfer and could be seen as the first phase to the total digitisation of deeds documents. The deeds registry system should, however, exist independently from the other role players involved in the South African conveyancing supply chain. This would add to the confidence and support of all role players and avoid the possibility of monopolies forming in the South African conveyancing supply chain. 'The relevant statutes need to cater for electronic communication and digital signatures' would have 'to be amended to overcome the barriers that would delay the introduction of an 
e-conveyancing system in' South Africa. Lastly, it is further 'recommended that automatic electronic registrations of property transfers be implemented' together 'with corresponding automatic and electronic payments to all relevant parties to the transaction' (Amadi-Echendu 2013).

In the final analysis, increasing cooperation and collaboration between the various entities involved in the property supply chain would help to reduce the delays and eliminate the bottlenecks experienced in the current end-to-end property process. Although the number of role players involved in property transactions cannot be reduced because of the unique roles fulfilled by each, it can be argued that approaching such property transactions using such a supply chain approach would improve the efficiency of the entire process.

\section{Acknowledgements}

Prof. Louis P. Krüger acknowledges the late Prof. Chris Kapp through his teachings and subsequent personal notes he took entitled 'Eagle eye view of mapping an article' at a 'Writing for publication' workshop presented by Prof. Kapp between 03 and 08 March 2013 at Arniston, Western Cape Province.

\section{Competing interests}

The authors declare that they have no financial or personal relationships which may have inappropriately influenced them in writing this article.

\section{Authors' contributions}

A.P.A-E. wrote the manuscripts and L.P.K. reviewed a number of drafts of the article and suggested certain structural changes and the inclusion of empirical data in the article. Specific written changes were made and added in the abstract, the introduction and the conclusion of the article.

\section{References}

Amadi-Echendu, A., 2013, 'An analysis of conveyancing business processes in South Africa', M.Com dissertation, University of Pretoria, Pretoria.

Amadi-Echendu, A.P. \& Amadi-Echendu, J.E., 2013, 'Legal aspects of engineering asset management', in World Congress on Engineering Asset Management's 8th Annua International Conference, Hong Kong, China, October 30 - November 1, 2013.

Amadi-Echendu, A.P. \& Pellissier, R., 2013, 'Lessons for South Africa from the international e-conveyancing environment', in Global Business and Technology Association's 15th Annual International Conference, Helsinki, Finland, July 2-6, 2013.

Badea, A., Prostean, G., Goncalves, G. \& Allaoui, H., 2014, 'Assessing risk factors in collaborative supply chain with the analytic hierarchy process (AHP)', Procedia Social and Behavioral Sciences 124, 114-123.

Blumberg, B., Cooper, D.R. \& Schindler, P.S., 2008, Business research methods, 2nd edn., McGraw-Hill Education, Maidenhead, UK.

Cheng, C.Y., Chen, T.L. \& Chen, Y.Y., 2014, 'An analysis of the structural complexity of supply chain networks', Applied Mathematical Modelling 38(9), 2328-2344.

Cheng, J.H., 2011, 'Inter-organizational relationships and information sharing in supply chains', International Journal of Information Management 31(4), 374-384.

Christopher, M.L., 1992, Logistics and supply chain management, Pitman, London, UK.

Christopher, M.L., 1999, Logistics and supply chain management: Strategies for reducing cost and improving service, Pitman, London, UK.

Cooper D.R. \& Schindler, P.S., 2006, Business Research Methods, McGraw-Hill Irwin, New York.
Creswell, J.W. \& Plano Clark, V.L., 2011, Designing and conducting mixed methods research, 2nd edn., Sage, Thousand Oaks, CA.

Deeds Registries Act, viewed 17 August 2015, from http://www.ruraldevelopment.gov. za/phocadownload/Acts/deeds $\% 20$ registries $\% 20$ act $\% 2047 \% 20$ of $\% 201937$.pdf

Denzin, N.K., 1978, The research act: $A$ theoretical orientation to sociological methods, 2nd ed., McGraw-Hill, New York.

Devaraj, S., Krajewski, L. \& Wei, J.C., 2007, 'Impact of eBusiness technologies on operational performance: The role of production information integration in the supply chain', Journal of Operations Management 25(6), 1199-1216.

Dong, S., Xu, S. \& Zhu, K.X., 2009, 'Information technology in supply chains: The value of IT enabled resources under competition', Information Systems Research 20(1), $18-32$.

Goldratt, E.M. \& Cox, J., 1992, The goal: A process of ongoing improvement, 2nd edn., North River Press, Great Barrington, USA

Gordon, R., Nell, M. \& Bertoldi, A., 2007, Overview of urban land as a commodity in South Africa: Research findings and recommendations, Matthew Nell and Associates (Pty) Ltd. viewed 11 March 2016, from http://www.urbanlandmark. org.za/downloads/Commodity_Final_Report.pdf

Hartono, E., Li, X., Na, K.S. \& Simpson, J.T., 2010, 'The role of the quality of shared information in inter-organizational systems use', International Journal of Information Management 30(5), 399-407.

Inda, S., Abu Bakar, H., Rohaizat, B. \& Rosman, Y., 2012, 'The study of supply chain management strategy and practices on supply chain performance', Procedia Social and Behavioral Sciences 40, 225-233.

Johnson, R.B., 1997, 'Examining the validity structure of qualitative research', Education 118(2), 282-292.

Koçoğlu, İ., İmamoğlu, S.Z., İnce, H. \& Keskin, H., 2011, 'The effect of supply chain integration on information sharing: Enhancing supply chain performance', Procedia - Social and Behavioral Sciences 24, 1630-1649.

Lambert, D.M., Stock, J.R. \& Ellram, L.M., 1998, Fundamentals of logistics management, Irwin/McGraw-Hill, Boston, MA.

Li, L., 2012, 'Effects of enterprise technology on supply chain collaboration: Analysis of China-linked supply chain', Enterprise Information Systems 6(1), 55-77.

Long, Q., 2014, 'An agent-based distributed computational experiment framework for virtual supply chain network development', Expert Systems with Applications 41(9), 4094-4112.

Lofti, Z., Mukhtar, M., Sahran, S. \& Zadeh, A.T., 2013, 'Information sharing in supply chain management', Procedia Technology 11, 298-304.

Loke, S.P., Downe, A.G., Sambasivan, M. \& Khalid, K., 2012, 'A structural approach to integrating total quality management and knowledge management with supply chain learning', Journal of Business Economics and Management 13(4), 776-800.

Mentzer, J.T., DeWitt, W., Keebler, J.S., Min, S., Nix, N.W., Smith, C.D. \& Zacharia, Z.G., 2001, 'Defining supply chain management', Journal of Business Logistics 22(2), $1-25$.

Muller, M. \& Seuring, S., 2007, 'Reducing information technology-based transaction costs in supply chains', Industrial Management and Data Systems 107(4), 484-500.

Ngai, E.W., Chau, D.C. \& Chan, T.L.A., 2011, 'Information technology, operational, and management competencies for supply chain agility: Findings from case studies', The Journal of Strategic Information Systems 20(3), 232-249.

Nieuwenhuizen, C. \& Rossouw, D., 2008, Business management: A contemporary approach, Juta, Cape Town, South Africa.

Oliva, R. \& Watson, N., 2011, 'Cross-functional alignment in supply chain planning: A case study of sales and operations planning', Journal of Operations Management 29(5), 434-448.

Page, C. \& Meyer, D., 2006, Applied research design for business and management, McGraw-Hill, Sydney, Australia.

Pearce, J.A. \& Robinson, R.B., 2005, Strategic management: Formulation, implementation and control, McGraw-Hill, Boston, MA.

Premkumar, G., Ramamurthy, K. \& Crum, M., 1997, 'Determinants of EDI adoption in the transportation industry', European Journal of Information Systems 6, 107-121.

Ramwell, D., Brink, P. \& West, A.S., 2008, Study guide: Conveyancing, University of South Africa, Pretoria.

Republic of South Africa, 1981, Alienation of Land Act of 1981, viewed 17 August 2015, from http://www.plato.org.za/pdf/legislation/Alienation $\% 20$ of $\% 20$ Land $\% 20$ Act $\% 2068 \% 20$ of $\% 201981$.pd

Sanders, N.R., 2005, 'IT alignment in supply chain relationships: A study of supplier benefits', The Journal of Supply Chain Management 41(2), 4-13.

Saunders, M., Lewis, P. \& Thornhill, A., 2003, Research Methods for Business Students, 3rd ed., Prentice Hall, Harlow, England.

Simatupang, T.M. \& Sridharan, R., 2002, 'The collaborative supply chain', The International Journal of Logistics Management 13(1), 15-30.

Slack, N., Chambers, S. \& Johnston, R., 2010, Operations management, Pearson Education, London, UK.

Stair, R. \& Reynolds, G., 2012, Principles of information systems, 10th edn., Course Technology, Boston, MA.

Strauss, A. \& Corbin, J., 1998, Basics of qualitative research: Procedures and techniques for developing grounded theory, Sage, Thousand Oaks, CA

Tan, F.T.C., Pan, S.L. \& Zuo, M., 2014, 'The role of organisational interdependencies and asset orchestration in business integration: A case study of MCom' International Journal of Information Management 34(6), 780-784. 
Thun, J.H., 2010, 'Angles of integration: An empirical analysis of the alignment of internet-based information technology and global supply chain integration', Journal of Supply Chain Management 46(2), 30-44.

Union of South Africa, 1937, Deeds Registry Act of 1937, viewed 16 August 2015, from http://www.ruraldevelopment.gov.za/phocadownload/Acts/deeds $\% 20$ registries $\% 20$ act $\% 2047 \% 20$ of $\% 201937$.pdf

Van der Walt, A.J. \& Pienaar, G.J., 1999, Introduction to the law of property, 3rd edn., Juta, Cape Town, South Africa.
Wong, C., Skipworth, H., Godsell, J. \& Achimugu, N., 2012, 'Towards a theory of supply chain alignment enablers: A systematic literature review', Supply Chain Management: An International Journal 17(4), 419-437.

Ye, F. \& Wang, Z., 2013, 'Effects of information technology alignment and information sharing on supply chain operational performance', Computers and Industrial Engineering 65(3), 370-377.

Yu, W., Jacobs, M.A., Salisbury, W.D. \& Enns, H., 2013, 'The effects of supply chain integration on customer satisfaction and financial performance: An organizational learning perspective', International Journal of Production Economics 146(1), 346-358. 